\title{
The influence of Azusa Street Revival in the early developments of the Apostolic Faith Mission of South Africa
}

\section{Mookgo Solomon Kgatla ${ }^{1}$}

\begin{abstract}
This article examines the influence of Azusa Street Revival in the early developments of the Apostolic Faith Mission (AFM) of South Africa. The link between AFM and Azusa Street Revival came through the American Missionaries, John G Lake and Thomas Hezmalhach who prior to their trip to South Africa had contact with William Seymour of the Azusa Street Revival, Los Angeles. Azusa Street Revival was characterised by Spirit baptism with the evidence of speaking in other tongues and non-racialism. Upon their arrival in South Africa, John G Lake and Thomas Hezmalhach influenced African Pentecostal like Elias Letwaba. They used Central Tabernacle Congregation as a place of fellowship. Meetings in this congregation were characterised by similar acts to what happened at Azusa Street Revival, Los Angeles. The article argues that the services hosted by American missionaries were characterised by Pentecostal experiences and non-racialism. This article concludes that the main impact of Azusa Street Revival in the early developments of the AFM of South Africa was its ability to unite people beyond their differences of race, gender, age and color and Pentecostal experiences.
\end{abstract}

\section{Introduction}

This article demonstrates the influence of Azusa Street Revival in the early developments of the Apostolic Faith Mission (AFM) of South Africa. This will be done by studying the Azusa Street Revival in context, the role played by William Seymour and the characteristics of the Revival. The article also studies the influence of Azusa Street Revival on the pioneers of Pentecostalism in South Africa, John G Lake and Thomas Hezmalhalch, African Pentecostal like Elias Letwaba and the Central Tabernacle Congregation. The purpose of this article is to demonstrate that the main impact of Azusa Street Revival in the early developments of the AFM of South Africa was its ability to unite people beyond their differences of race, gender, colour, age and others in a hostile political environment and Pentecostal experiences.

Dr Solomon Kgatle is a research associate of Prof Dr Ernest van Eck in the Department of New Testament Studies, University of Pretoria. He can be contacted at kgatles@yahoo.com 


\section{Azusa Street Revival in American context}

\subsection{William Seymour}

William Joseph Seymour was born on May 2, 1870, in Centerville, Louisiana. His parents were released slaves who used to work on the cotton plantations in the south of the United States. Seymour was raised in a Baptist church, but when he took up a job as a waiter in Indianapolis, Indiana, he became a member of the Black Methodist Episcopal Church. When he moved to Cincinnati, Ohio, he joined the Evening Light Saints church, which was in the holiness fold. Again, when he moved to Houston, Texas, in pursuit of his family, he became associated with a Black Holiness Church which had a woman, Lucy Farrow, as pastor (Lapoorta 1996:29).

William Joseph Seymour became a student at Parham's Bible School in Houston. It was at this school where he was taught about the initial evidence doctrine, by Parham. Although he did not experience the baptism of the Holy Spirit in Houston, he firmly believed that it was a necessity for every believer and those who spoke in tongues evidenced outward manifestation thereof (see Lapoorta 1996:29). The twentieth century Pentecostal Movement in America originated from the womb of Black religious experience. It was through Azusa Street in Los Angeles in 1906 to the world that the Pentecostal Movement has ushered in the era of the Holy Spirit (Lovett 1972:42).

William Seymour, a Black Holiness preacher and a student of Parham (a White man) in Houston, carried the new message to Los Angeles and became one of the key leaders in the Pentecostal revival, which occurred in a former African Methodist Episcopal church in Azusa Street (McGee 1988:58). William Seymour's religious experiences represent a consistent merging of African and new world components which persisted in precisely those churches which are closest to the Black masses. The central place of such experiences and encounters is Azusa Street in Los Angeles (Poewe 1988:145).

He assured followers that if they prayed for weeks with sufficient earnestness, God was ready to send a new Pentecost. Like the miraculous event described in Acts, this latter-day outpouring of the Spirit would be demonstrated with tongues of flame, healing, speaking in tongues, and other signs and wonders (Cox 1995:37). At Azusa, Blacks, Whites, Hispanics, and Europeans met and worshiped together. They crossed formerly impossible cultural lines. Although the success of the revival was short-lived, we still enjoy its fruits. Today, Azusa remains a common word within God's household (Liardon 1996:125).

William Seymour endorsed tongues to be a sure sign of the baptism in the Holy Spirit. He also found that speaking in tongues alone was an insufficient sign. Seymour discovered that some White people could speak in tongues and continue to treat peo- 
ple of colour as inferior to them (De Kock 2000:109). While speaking in tongues could serve as evidence of the baptism in the Holy Spirit even as initial evidence, it was not considered absolute evidence. Seymour believed that tongues accompanied by the dissolution of racial barriers were the indisputable sign of the Holy Spirit.

In the years between 1906 and 1909 the Azusa Street Mission became the focus of attention of thousands of people around the world. Stories of what was happening were carried in both secular and Christian press and much of it not very complimentary. So if anyone deserves the right to be recognised as the founder of modern day Pentecostalism it must be William Seymour. It was his vision, leadership, teaching and drive which kept the movement on track (Letson 2007:114).

He summed up the evangelistic and missionary focus and impact of his work during the first decade of its existence. He viewed the purpose of the mission, indeed, of the 'Apostolic Faith' people as a whole, as evangelisation of the entire world. During that decade (1906-1915), Seymour had witnessed the teachings of the 'Apostolic Faith' including the call to personal repentance and faith, the pursuit of personal and corporate holiness, and the acceptance of power for ministry through the baptism in the Holy Spirit (Robeck 2007:78).

William Seymour preached a message which highlighted the empowerment of Spirit baptism as the necessary force by which a new type of community where race, gender and ethnicity would not be categories of division (Klaus 2007:40). This multicultural perspective can be summarised as focusing on a new community of justice and equity. The anticipation and participation in this new community as a full member certainly could be viewed as a liberating experience by any definition.

In addition, Afro-Pentecostal rituals permit and promote participation with varieties of experiences, perceptions, movements, styles, roles, gifts and talents. There is something for anyone and everyone to do (Leatherman 2008:918). The hesitant and insecure are most encouraged when they take the risk to participate. Invitation to personal action, whether building a habitat for humanity house or Afro-Pentecostal worship, encourages participation. The name of William Seymour, an unlettered Black minister with vision in only one eye, is central to the historic events of Azusa Street (Khathide 2010:61).

\subsection{Characteristics of Azusa Street Revival}

Azusa Street Revival is a Pentecostal revival meeting that happened in 1906, United States of America, Los Angeles. The revival which was led by an African American, William J Seymour was characterised by Spirit baptism with the evidence of speaking in other tongues, miracles and other spiritual experiences. The revival attracted people in the United States of America and the world. Azusa Street Revival lasted for more than eight years from 1906 until 1915. 
The Azusa Street Revival according to Omenyo (2006:247) was significant in many respects: First, it was second to none in terms of its reach and the depth of its influence both in the United States and abroad. This consequently led to the emergence of several centres of Pentecostalism in cities throughout the United States. It thus produced many Pentecostal denominations. Second, and more significant, is the unprecedented number of missionaries that the Azusa Street Revival produced. Within five months of the birth of this movement, thirty-eight missionaries had gone out from Azusa. In only two years it had spread to over fifty nations worldwide. The nations include China, India, Japan, the Philippines, South Africa, the Middle East and Liberia.

Azusa Street Revival was anticipated for a long time Azusa Street. It claimed to be the definitive formula and a sure beginning of the end-time revival. Azusa Street fulfilled all revival hopes that were transmitted through the missionary (Bergunder 2007:65). Azusa became the central mythic event for early Pentecostals because they perceived it to be the location where God initiated an eschatological plan for the restoration of the church (Creech 1996:407).

Azusa Street prayer meetings were begun and before long, wonderful scenes took place. There were prostrations, strong crying unto God, weeping and manifestations of joy. Most notable of all, those who were filled with the Holy Spirit experienced physical manipulation of face and body and the final exercise of speaking in tongues as the Spirit of God gave utterance (McDonnell 1996:610). The Pentecostal experiences in Azusa are similar to the ones in the book of Acts 2. These Pentecostals believed the cornerstone of this restoration was the duplication of the first Pentecost. Azusa was signified by the re-enactment of the Apostle's experiences recorded in Acts 2 . It was signified by the baptism of the Holy Spirit accompanied by speaking in tongues.

The Azusa Street Revival came to symbolise early Pentecostal's theological assumptions and especially their eschatological hopes. As a symbolic point of origin, Azusa offered theological and historical meaning for the Pentecostal experience and the movement itself. Azusa Street went global from the very start and began to channel their message through the vast international evangelical and missionary network that was receptive to revivals.

At Azusa Street Mission a more symbolic correlation began to emerge alongside their more inclusive understanding of the results of Spirit baptism. The ability to speak in tongues was understood as an avenue of praise to God that symbolised the heavenly praise that would soon be instituted in the rapture. The idea of tongues as a private prayer language also began to emerge in Apostolic Faith as a symbol of a direct communion with God reminiscent of Parham's notion of 'the anointing that abides'. Speaking in tongues was increasingly seen as an experience that in different ways symbolised the many varied blessings and benefits of Spirit baptism testi- 
fied to by people at Azusa Street (Friesen 2009:52). The subsequent meetings that were held in the former Methodist church at 312 Azusa Street in Los Angeles have consequently come to be referred as Azusa Street Revivals (Machingura 2011:16). The Azusa Street Revival had two main characteristics, the Pentecostal experiences and non-racialism.

\section{The political situation in South Africa before the arrival of John G Lake and Thomas Hezmalach}

The political situation in South Africa just before the arrival of the American missionaries, John G Lake and Thomas Hezmalach was very tense. It was a situation of the Anglo-Boer wars. The first Anglo-Boer (1880-1881) is also known as the first Transvaal war of independence because the conflict arose between the British colonisers and the Boers from the Transvaal republic. According to Morgan 2002:1) it was caused by the expansion of the British empire, problems within the Transvaal government, the British annexation of the Transvaal and the Boer opposition to British rule.

The second Anglo-Boer war (1899-1902) was caused by the political ideologies of imperialism and the republicanism, the discovery of gold on the Witwatersrand, tension between political leaders, the Jameson Raid and the Uitlander franchise (Ross 2006:1). During the immediate post-war years the British focussed their attention on rebuilding the country, in particular the mining industry. By 1907 the mines of the Witwatersrand produced almost one-third of the world's annual gold production. The Afrikaners found themselves in the ignominious position of poor farmers. The Blacks and the coloureds remained marginalised in society. The British High Commissioner Lord Alfred Milner introduced "segregation" also known as apartheid in South Africa (South African history online 2011).

Segregation denotes a complex amalgamation of political, ideological and administrative strategies designed to maintain and entrench White supremacy at every level. It was elaborated in the context of South Africa's experience of rapid industrialisation and was intended to defend the prevailing social order from the threat posed by the growth of a potentially militant African proletariat. As an ideological justification of political inequality, segregation was founded on a dual principle that first, was the recognition of an African's right to land ownership which was conditional on the sacrifice of their claims for common citizenship. Second, that Africans were the wards of their White 'trustees', under whose benevolent guidance they would be encouraged to develop autonomously (Dubow 1989:1).

Racial segregation was an economic policy for societal advantage through political, ideological and administrative strategies. Sibeko and Haddad (1997:84) adds that the system of apartheid guaranteed that political, economic, and cultural power was controlled by the White minority. Social deprivation was heightened even fur- 
ther by the policy of separate development resulting in the forced removal of millions of people from their homes. A restrictive urbanisation policy directed towards African people, implemented through pass laws and influx control measures.

Through the vein of religion, for example, the apartheid system in South Africa enabled Whites to establish superiority in a land where they were, in fact, the minority. Through the system, Whites would come to possess eighty seven percent of South Africa's land and wealth, leaving the Black African population a diminutive thirteen percent. This system of classification proved economically beneficial for Whites (Howard 2006:143). As indicated earlier, Africans were a majority and as a result they could not be marginalised without segregation. The purpose of racial segregation was to divide the African majority into ethnic groups and to channel African political and economic aspirations towards the bantu-stands which would be the 'homelands' for those ethnic groups. A further purpose was to deprive all Africans of South African citizenship thereby turning African workers in White areas into 'foreign' visitors (Maylam 2001:195).

Although segregation was predicated on perceptions of racial difference and was developed in the aftermath of colonial conquest, South African segregation was not just racial subordination. Its underlying principle was the enforced separation, not just subordination, of Blacks and Whites in the spheres of work, residence and government (Worden 2012:80). Racial segregation was reinforced by the increasing institutionalisation of apartheid policies. This was especially so after the gazetting of the so-called 'church clause' of the Native Laws Amendment Bill in 1957, which attempted to force racial segregation by restricting 'Black' people from attending services in designated White' residential areas (Czegledy 2008:289).

\section{The important role players in the AFM of South Africa}

\subsection{John G Lake and Thomas Hezmalach}

The Azusa Street Revival had an influence on the founders of the AFM of South Africa, John G Lake and Thomas Hezmalhach. While John G Lake was busy conducting a gospel campaign in North Western Illinois, he felt the deep burning urge to come to South Africa with the intention of preaching the gospel (Lapoorta 1996:49). The American missionaries had no organisation behind them, and had only been able to buy one way tickets due to the last moment generosity of a friend (Maxwell 1999:246).

In January of 1908, Lake began to pray for the needed finances to take the Africa trip. Thomas Hezmalhalch joined him, and they determined the trip would cost two thousand United States Dollars. Exactly four days later, they received the money for the trip. In April of 1908, the group left for Africa. The team was made up of Lake, Jennie his wife, their seven children, Thomas Hezmalhalch, and three of his companions. 
This demonstrates that the missionary team that God had sent to Africa was a team of faith and determination. They did not rely on their own strength and might but only on the provisions of the Lord. These American missionaries were also ready to give up their comfort zone in order to follow the calling of God in their lives. They showed a strong characteristic of leadership 'sacrifice'. They were not self-centred and did not run after positions. They discovered that 'Zion' taught immersion and divine healing, but not Pentecost. Meetings were first conducted in conjunction with the Apostolic Faith Church in Zion as the Christian Catholic Church as it was known in South Africa at that time (Hollenweger 1972:120).

John G Lake and other American Pentecostal missionaries to South Africa received the teaching of 'Spirit baptism' at Azusa Street. Lake visited Azusa Street on several occasions and he described Seymour as having 'more of God in his life than any man he had ever met up to that time'. The relationship between Lake and Seymour was a concrete one. It appears that Seymour was a 'spiritual father' to Lake and multitudes of Pentecostals. Lake revisited Azusa Street on at least one occasion to report to Seymour about what was happening in South Africa (Anderson 1996:117). Lake and Seymour maintained contact with each other and they shared their experiences even after Lake returned from South Africa (Lapoorta 1996:23).

John G Lake and Thomas Hezmalhalch were influenced by Pentecostalism of the Apostolic Faith Church through Azusa Street, Los Angeles where the outpourings of the Holy Spirit took place (Oosthuizen 1987:11). Lake was acquainted with Seymour. Both Thomas Hezmalhalch and John G Lake visited William Seymour in Azusa Street (Roy 2000:121). It means that John G Lake and Thomas Hezmalhalch did not only come to South Africa as independent ministers, but also came with the Azusa Street Revival influence.

In addition, the arrival of John G Lake and Thomas Hezmalhalch influenced the founding of the AFM and other churches as well. According to Fatokun (2005:163) John G Lake began to spread the Pentecostal message throughout the nation. This enterprise resulted in the founding of two large influential and Pentecostal churches in South Africa 'Apostolic Faith Mission' in 1910 and 'Zion Christian Church'

The main missionary leaders continued to work together and shared responsibilities. When John G Lake and Thomas Hezmalhalch started Pentecostal work in South Africa, they worked as a team of equals. After localising the work at the Bree Street Tabernacle, they acted as co-ministers of that congregation. The first set of minutes from a meeting of those early workers was dated 17 September 1908. In the months following, meetings were regularly held two or three times a month. It is noteworthy that no leader or president was appointed at this stage. Hezmalhalch's name would appear first in the list of those present (Burger \& Nel 2008:35). 
John G Lake spent the rest of 1910-1912 ministering healing as he prayed for the sick. Great miracles were performed that still affect Africa today. Lake and his congregation regularly published a newsletter that was mailed to thousands of people. Before they were mailed, church members would lay hands on them and pray that the pieces of literature would be filled with God's Spirit. They believed the power of God would anoint the newsletter's paper, just as it occurred with the handkerchiefs of Paul. As a result, thousands of letters would pour in from all parts of the world, stating how the Spirit of God came upon the recipients as they opened the paper (Clark 2012:3).

In short, John G Lake and Thomas Hezmalhalch together with their team came in 1908 to South Africa with the Azusa Street Revival influence through William Seymour. They came to South Africa by faith without any support from a missionary organisation to support their missionary work in Africa. When they arrived they conducted services in Doornfontein Zionist Church but soon moved to Bree Street Central Congregation also belonging to the Zionist movement. The two leaders continued to work together and sharing responsibilities until their departure back to the United States.

\subsection{Elias Letwaba}

The azusa street revival had an influence on the African Pentecostal Elias Letwaba. Letwaba was one of the first African Pentecostals in South Africa and quite influential. He was mentioned in the Executive Council minutes of the AFM of South Africa in February 1909 and considered to be one of the most outstanding Black leaders in the history of the AFM of South Africa. Letwaba was born in the former Northern Transvaal (now Limpopo Province) around 1870, after his mother had received a remarkable revelation about his future. His father, an Ndebele Christian, did not allow his son to attend the customary initiation school and Letwaba was raised in a Christian environment. At the age of fourteen he rescued a man from drowning in a river and he felt called by God to rescue men and women out of the black river of sin and death (Anderson 1996:125).

Elias Letwaba was a respected minister in the church at the time he met John G Lake at the beginning of 1909. Letwaba was so impressed by the miracles of God's power that he decided to stay with Lake in his home to learn from him. He accompanied Lake on his journey to Bloemfontein and received the Pentecostal 'baptism' there in February 1909. Embarking on an evangelistic tour of the Northern Transvaal, his home province, he walked many hundreds of miles, preaching the gospel of salvation, healing and baptism of the Holy Spirit. His teachings were the main fundamental teachings of the Pentecostal Movement. One of the highlights of Letwaba's achievements was the establishment in 1930 of the Patmos Bible School, 
the first theological training facility for Blacks in the AFM of South Africa (Roy 2000:122).

Burger and Nel (2008:386) highlights the fact that in spite of political and economic difficulties pastor Elias Letwaba, the Black overseer of Northern Transvaal, was able to fulfil Bible education without financial guarantees. His 'Black' Bible School paved the way for the development of a Pentecostal theological educational institute with roots in Africa. His faith and determination made him the pioneer of theological education in the AFM, being the principal of the first Bible School. In addition to the Patmos Bible School, a primary school with 150 pupils was established next to the Bible School.

Elias Letwaba was one of the first Black leaders of the AFM of South Africa, a man whose ministry in the northern parts of the country led to the establishment of a large African church (Clark 2012:3). In addition Letwaba was a humble man who accepted the racial indignities imposed upon him by White church leaders. His influence in the church was his powerfully charismatic evangelistic ministry and his involvement in theological training.

In summary, Letwaba was called for the work of ministry at a very tender age of fourteen. Since then, he never looked back and today he is considered to be one of the first African Pentecostals in the AFM of South Africa. He preached a Pentecostal message of salvation, divine healing and the baptism in the Holy Spirit which is in line with the teaching of a Pentecostal Movement. He founded and led a Bible School called 'Patmos Bible School' which also registered pupils in primary school. And with all these accolades he remained humble and obedient to White superiority.

\subsection{Central Tabernacle Congregation}

Azusa street revival had an influence on Central Tabernacle congregation. Central Tabernacle congregation played a significant role in the early developments of the AFM of South Africa. Lapoorta (1996:50) describes the events as follows: Meetings of American missionaries commenced in a small Zionist Church in a Black residential area of Doorfontein, in Johannesburg. From the very first day numerous people were miraculously healed through prayer. It was at these meetings that the dividing walls of race and colour were erased by the blood of Jesus and through the move of the Holy Spirit. Due to the large numbers in attendance at the meetings the premises in Doornfontein became totally inadequate to accommodate the people. They had to move to the Central Tabernacle congregation.

Meetings at this congregation bore remarkable resemblances to the Azusa Street Revival, particularly in its initial multi-racial character. There were similar ecstatic phenomena such as glossolalia, 'holy laughter' shakings and prostrations under the 
power of the Spirit, and a pronounced public confession of sins. News of miraculous healings and conversions was propagated by word of mouth, and by the press which was often hostile. Members of other denominations came to see and often receiving Spirit baptism (Maxwell 1999:246).There were similar occurrences of Pentecostal experience of Azusa Street Revival in Los Angeles and at the Central Tabernacle congregation in Johannesburg, South Africa. Thus, a parallelism is drawn between Azusa Street and Bree Street in relation to the Pentecostal Movement (Roy 2000:121).

When John G Lake and Thomas Hezmalhalch came to South Africa, they used the Central Tabernacle congregation in Bree Street, Johannesburg which is similar to Azusa Street in Los Angeles in the Pentecostal Movement context. Just like at the Azusa Street Revival in this congregation there was a Pentecostal experience through prayer and many people received their healing and other miracles. There were no racial barriers or dividing walls of race and colour, they were erased by the blood of Jesus.

\section{The influence of Azusa Street Revival on the AFM of South Africa}

\subsection{Pentecostal experiences}

John G Lake received his mantle of Pentecostalism from William Seymour. As it has already been said above meetings at the Central Tabernacle Congregation were characterised by Pentecostal experiences. These include among others baptism in the Holy Spirit with the evidence of speaking in other tongues, miracles, signs and wonders.

The ministry of John G Lake was also characterised by divine healing. According to Nel (2016:65) Lake is seen as divinely inspired, directly sent by God to southern Africa, orchestrating massive healing campaigns using the laying on of hands to cure various diseases and infirmities, and performing other miracles such as resurrecting the dead. Kgatle (2015:175) says that John G Lake spent the rest of 1910-1912 ministering healing as he prayed for the sick. Great miracles were performed that still affect Africa today. Lake and his congregation regularly published a newsletter that was mailed to thousands of people. Before they were mailed, church members would lay hands on them and pray that the pieces of literature would be filled with God's Spirit. They believed the power of God would anoint the newsletter's paper, just as it occurred with the handkerchiefs of Paul. As a result, thousands of letters would pour in from all parts of the world, stating how the Spirit of God came upon the recipients as they opened thepaper.

John G lake passed the mantle to Elias letwaba Letwaba's ministry was characterized by reported healings and miracles. It was these miracles that really opened the doors for him (Anderson 1996:127). On one occasion, which John G Lake after- 
wards related to William J Seymour in Los Angeles. Letwaba was praying for a baby who had fallen and broken its neck. Lake went out of the room, as he did not have faith for a broken neck and did not want to interfere with Letwaba's faith. Letwaba carried on praying and the baby was healed (Lake 2011:32-33).

On another occasion he went to have meetings for the natives on a white man's farm. When he arrived there he was told to sleep in the fowl-house. He said, 'Thank you, baas', made a broom from twigs, and cleaned the place and went to sleep. At midnight he was awakened by the farmer who said, 'wake up, Letwaba, my wife is desperately ill, come and pray for her.' He got up immediately and prayed for the woman, who was healed instantaneously. The farmer then told him to go and sleep in an outside room, and apologised for putting him in a fowl-house, but Letwaba said, 'it is all right, sir, to put me there, my Master slept in a stable, and I am only a black worm ${ }^{2}$. For another two years Letwaba travelled, even going as far as Zimbabwe with his message. It is reported that during this time, more than ten thousand sick were permanently healed and over a hundred thousand souls were led to Christ (Lindsay 1972:51).

\subsection{Non-racialism}

The AFM of South Africa started as a non-racial church. Early attempts to introduce racial separation in worship were resisted by the founding missionaries. When the missionaries left the country to return to their homelands, the church was set on a course of racial separation in compliance with the racial ideology of the country. Protests by Blacks were not heeded because a paternalistic mentality characterised the White churches involvement with regard to the Black church (Paul 2006:78).

The position of American missionaries on either prohibiting or permitting racial segregation is argued by the fact that the founding missionaries in the person of John G. Lake and Thomas Hezmalhalch made a strong case for separate works among Black, Coloured, Indian and White congregations though under the umbrella of the AFM (Poewe 1988:147). In 1908 and 1909, AFM adopted policies that would doom its considerable initial growth in the more distant future. By the time John G Lake departed from South Africa in 1913, many Black leaders had already formed their own groups.

The minutes dated 17 September 1908, apparently at Lake's instigation, according to Roy (2000:122) show that the missionaries supported racial segregation. Lake spoke of the necessity of getting adequate accommodation for the holding of services in Doornfontein especially for the Coloured people. Less than two months later, they decided that, 'the baptism of natives shall in future take place after the

$\overline{2 \text { Comforter, June } 1959 .}$ 
baptism of the White people'. At the executive meeting in February 1909 it was decided that the superintendent over the 'native work' must be White. The minutes of July 1909 read: 'in future, the baptism of Whites, Coloured, Indians and Natives shall be separate'.

However it might be true that the poor missionaries were under social pressure because Pentecostals, like other churches in South Africa during apartheid, yielded to the pressures from White society and developed racially segregated churches. The AFM is a striking example of the differences in outlooks of White and Black members of the same church (Anderson 2001:3). The American missionaries supported racial segregation because to a certain extent they were stimulated by societal and racial mind-sets. In addition to practices in the country at that time and self-generated separation for reasons of language and cultural differences (Chandomba 2007:23).

Horn (1991:5) clarifies that during the first few months White and non-White were even baptised together, however at the end of 1908 some Afrikaans speaking brothers came onto the Executive Council. The fact that they understood the history and the nature of the racial feelings in South Africa better, possibly contributed to the gradual separation of the races. It is possibly correct to conclude that the pioneers deviated from non-racialism because of White racist pressure rather than theological conviction.

Another aspect of racial segregation was seen in the membership of the AFM as exemplified by Matika (2004:70) that until 1991, only White people could be legal members of the AFM. The church participated freely in the repressive government of racial segregation. It was eager to promote good relations with the traditional Afrikaner churches, especially the Dutch Reformed Church.

In 1944, four years before the National Party government took over, the AFM took a resolution that the mission stands for segregation that highlighted its support for the philosophy of apartheid. The fact that the Black, Indian and Coloured are saved does not render them European. The church also asserted its support for Bantu Education, that is, Native Education: The mission stands for a lower education [for Black people] but is definitely against a higher education.

The AFM of South Africa continued with the mission practice of 'daughter churches,' similar to that practiced by the Dutch Reformed Churches. The practice led to the establishment of four major groupings in the AFM: the White (parent) church, a large Black daughter church, a Coloured (mixed race) daughter church, and an Indian daughter church. The Black church consisted of many different components, ordered primarily by language and region (Clark 2005:144). A separate meeting hall was opened in which services could be held. It was a reversal of the initial interracial character of the movement that supported interracial worship between the movement's adherents. In addition the AFM instituted a series of racially 
motivated policies and structures whose effect was to fundamentally change the way in which persons participated in the church (Richardson 2013:29).

It is understood here that although the AFM of South Africa started as a racially integrated church. American missionaries adopted racial policies that were socially acceptable at that time to divide the church into four main sections namely the Black, Coloured, Indian and the White section. They did not do so because they believe in racial segregation. Therefore the meetings in the early AFM were non-racial, it is only at the departure of the American missionaries that the AFM became segregated.

\section{Conclusion}

This article has examined the influence of Azusa Street Revival in the early developments of the AFM of South Africa. It has demonstrated the link between AFM and Azusa Street Revival which came through the American Missionaries, John G Lake and Thomas Hezmalhach who prior to their trip to South Africa had contact with William Seymour of the Azusa Street Revival, Los Angeles. Azusa Street Revival was characterised by Spirit baptism with the evidence of speaking in other tongues and non-racialism. The conclusion is that the services hosted by American missionaries at the central Terbanacle Congregation were characterised by Pentecostal experiences and non-racialism. Therefore the main impact of Azusa Street Revival in the early developments of the AFM of South Africa was its ability to unite people beyond their differences of race, gender, age and color and Pentecostal experiences.

\section{References}

Anderson, A., 1996, African Pentecostalism, St Hist Eccl 22(2), 114-148.

Anderson, A., 2001, stretching the definitions? Pneumatology and syncretism in African Pentecostalism, Journal of Pentecostal Theology 10(1), 98-119.

Anderson, A., 2001, Pentecostals and Apartheid in South Africa during Ninety Years 19081998, Cyberjournal for Pentecostal-charismatic research, http://www.pctii.org.cyberj/index.html (1 March 2015).

Bergunder, M., 2007, Constructing Pentecostalism: On issues of methodology and representation, Journal of the European Pentecostal Theological Association, 26 (2), 55-73.

Burger, I. \& Nel, M., 2008, The Fire Falls in Africa, Christian Art, Vereeniging.

Chandomba, L., 2007, The History of the Apostolic Faith Mission and other Pentecostal Mission in South Africa, Authorhouse, Milton Keynes.

Clark, M., 2005, Two Contrasting Models of Missions in South Africa: The Apostolic Faith Mission and the Assemblies of God, Asian Journal of Pentecostal studies 8(1), 143-161

Coulter, D.M., 2012, The Spirit and the Bride Revisited: Pentecostalism, Renewal, and the Sense of History, Journal of Pentecostal Theology 21(1), 298-319.

Cox, H.,1995, Fire from Heaven: The Rise of Pentecostal Spirituality and the Reshaping of Religion in the Twenty-first Century, Cassell, London. 
Creech, J., 1996, Visions of Glory: The Place of the Azusa Street Revival in Pentecostal History, Church History 65(3), 405-424.

Czegledy, A., 2008, New Christianity in a New South Africa: Charismatic Christians and the Post- Apartheid Order, Journal of Religion in Africa 38(1), 284-311.

DeKock, W.J., 2000, Pentecostal Power for a Pentecostal Task: Empowerment Through Engagement in South African Context, Journal of Pentecostal Theology 16(1), 102-116.

Dubow, S., 1989, Racial Segregation and the Origins of Apartheid in South Africa, 19191936, Macmillan, Oxford.

Fatokun, S.A., 2005, Pentecostalism Globalization, Ogomoso Journal of Theology, 10(4), 159-170.

Fiedler, K., 1994, The Story of Faith Missions, Regnum, Oxford.

Friesen, A., 2009, The called out of the called out: Charles Parham's Doctrine of Spirit Baptism, The Journal of the European Pentecostal Theological Association, 42-54.

Hollenweger, W,J 1972. The Pentecostals. SCM Press, London.

Horn, N., 1991, Crossing Racial Borders in Southern Africa a lesson from history, cyberjournal for Pentecostal-Charismatic Research, http://www.pctii.org.cyberj/index.html (1 March 2015).

Howard, D.C., 2006, An Analysis of Black Power and Black Consciousness Philosophies and the use of Christian Religion as a Tool for Empowerment and Social Protest, PhD Thesis, Proquest, Department of African studies, Howard University, Washington.

Kgatle, M.S., 2015. Servant leadership in Mark 10: 35-45 applied to African Pentecostal Christianity (Doctoral dissertation, University of Pretoria).

Khathide, A.G., 2010, Hamba Vangeli Elisha: A Portrait of Rev Job Y Chiliza-Pioneer of the African Gospel Church, Acad SA, Kempton Park.

Klaus, B.D., 2007, Pentecostalism and Mission, Missiology: An International review 1(1), 39-54.

Lapoorta, J.J., 1996, Unity or Division? The unity struggle of the black churches within the Apostolic Faith Mission of South Africa, Department of religious studies, university of the Western Cape, Bellville, Cape Town.

Leatherman, C.G., 2008, Anthropology, Polanyi and afro-Pentecostal ritual: A Scientific and Theological Epistemology of Participation, Zygon 43(4), 909-923.

Letson, H., 2007, Pentecostalism as a paradigm shift: a response to Hans Kung's paradigmatic model, Journal of the European Pentecostal Theological Association 27(2), 104-117.

Liardon, R., 1996, God's generals: Why they succeeded and why some failed, Tulsa, Oklahoma, Albury.

Lindsay, G., 1972,John G Lake-Apostle to Africa, Dallas, Texas, Christ for the Nations

Lovett, L., 1972, Perspective on the black origins of the contemporary Pentecostal Movement, Journal of I.T.C 1(1), 6-49.

Machingura, F., 2011, The significance of glossolalia in the apostolic faith mission, Zimbabwe, Studies in world Christianity 17(1), 12-29.

Matika, B.M., 2004, Religion and the advent of democracy in South Africa, MA Dissertation, Graduate school, Texas Woman's University. 
Maxwell, D., 1999, Historicizing Christian independency: The Southern African Pentecostal Movement 1908 to 1960, Journal of African History 40(2), 243-264

Maylam, P., 2001, South Africa's racial past: the history and historiography of racism, segregation, and apartheid, Ashgate, Aldershot.

McDonnel, K., 1966, The Ecumenical Significance of the Pentecostal Movement, Worship 40(10), 608-629.

McGee, G.B., 1988, The Azusa Street Revival and twentieth-century missions. International Bulletin of Missionary Research, 58-61.

Morgan, K.O., 2002. The Boer War and the media (1899-1902). Twentieth Century British History, 13(1), pp.1-16.

Nel, M., 2016. John G. Lake as a fraud, con man and false prophet': critical assessment of a historical evaluation of Lake's ministry. Studia Historiae Ecclesiasticae, 42(1), pp.1-24.

Omenyo, C.N., 2006, William Seymour and African Pentecostal historiography: the case of Ghana, Asian Journal of Pentecostal Theology 9(2), 244-258.

Oosthuizen, G.C., 1987, The Birth of Christian Zionism in South Africa, University of Zululand, KwaDlangezwa.

Paul, S.A., 2006, Deconstructing a South African narrative of oppression: the influence of religion in public policy: Christianity in South Africa 1948-2004; exploring the African narrative of ubuntu, PhD Thesis, Proquest Information and Learning Company, Department of practical theology, Fuller Theological Seminary, Pasadena.

Poewe, K.0., 1988, Links and parallels between black and white charismatic churches in South Africa and the States: Potential for Cultural Transformation, Pneuma 10(2), 141-158.

Pomerville, P.A., 1982, Pentecostalism and missions: distortion or correction? The Pentecostal contribution to contemporary mission, university microfilms international, Fuller Theological Seminary, Pasadena.

Richardson, L.K., 2013. What has Pentecostalism to do with race relations? A study of the Apostolic Faith Mission In South Africa? school of divinity, regent university.

Robeck, C.M., 2007. Pentecostalism and Mission from Azusa Street to the ends of the earth, Missiology: an International Review 35(1), 75-92.

Ross, H.M., 2006. A woman's world at a time of war: an analysis of selected women's diaries during the Anglo-Boer War 1899-1902 (Doctoral dissertation, Stellenbosch: University of Stellenbosch).

Roy, K., 2000,Zion City RSA: the story of the church in South Africa, South African Baptist Historical Society, Pretoria.

Sibeko, M \& Haddad, B., 1997, Reading the Bible "with" women in poor and marginalized communities in South Africa, Semeia 78(1), 83-92.

South African History online, 2011/. Retrieved at www.sahistory.org.za on 16 february 2017

Waldo, C, 2000, Daily life and transcendence in Pentecostalism, in Shaull, R \& Waldo C (eds) Pentecostalism and the future of the Christian churches: Promises, limitations, challenges, pp. 3-111, William B Eerdmans, Grand Rapids, Michigan.

Worden, N., 2012, The making of modern South Africa: conquest, apartheid, democracy, (5th edition), Wiley-Blackwell, Chichester, West Sussex. 